\title{
A new genus and nine new species of Neotropical spittlebugs (Hemiptera, Cercopidae, Tomaspidinae)
}

\author{
Gervasio S. Carvalho ${ }^{1} \&$ Michael D. Webb ${ }^{2}$
} 'Pontifícia Universidade Católica do Rio Grande do Sul. Caixa Postal 1440, 90619-900 Porto Alegre-RS, Brazil. E-mail: gervasio@pucrs.br
${ }^{2}$ The Natural History Museum. Cromwell Road, London SW7 5BD,UK. E-mail: mew@nhm.ac.uk

\begin{abstract}
Resumo. Um gênero novo e nove espécies novas de cigarrinhas Neotropicais (Hemiptera, Cercopidae, Tomaspidinae). Os seguintes novos táxons de Cercopidae sul-americanos são descritos: Ferorhinella gen. nov., com a espécie-tipo Sphenorhina brevis Walker, 1851; Deois (Deois) knighti sp. nov. (Brasil), Deois (Deois) sexpunctata sp. nov. (Brasil), Deois (Pandysia) constricta sp. nov. (Brasil), Mahanarva (Ipiranga) bahiaensis sp. nov. (Brasil), Maxantonia bifurcata sp. nov. (Brasil), Neosphenorhina curvipenis sp. nov. (Brasil), Sphenorhina brevispina sp. nov. (Equador), Sphenorhina nigricephala sp. nov. (Equador), Sphenorhina minuta sp. nov. (Brasil), Tropidorhinella onorei sp. nov. (Colômbia), Zuata luteofascia sp. nov. (Colômbia). Ferorhinella brevis (Walker, 1851) comb. nov. São fornecidas, também, descrições de um novo padrão de colorido de Mahanarva (M.) phantastica (Breddin, 1904) e de uma variação constatada recentemente na genitália do macho de Deoisella fasciata Costa \& Sakakibara, 2002.
\end{abstract}

Palavras-Chave. Cercopidae; Hemiptera; Neotropical; novos táxons.

Abstract. The following new taxa of South American Cercopidae are described: Ferorhinella gen. nov., with type species Sphenorhina brevis Walker, 1851; Deois (Deois) knighti sp. nov. (Brazil), Deois (Deois) sexpunctata sp. nov. (Brazil), Deois (Pandysia) constricta sp. nov. (Brazil), Mahanarva (Ipiranga) bahiaensis sp. nov. (Brazil), Maxantonia bifurcata sp. nov. (Brazil), Neosphenorhina curvipenis sp. nov. (Brazil), Sphenorhina brevispina sp. nov. (Ecuador), Sphenorhina nigricephala sp. nov. (Ecuador), Sphenorhina minuta sp. nov. (Brazil), Tropidorhinella onorei sp. nov. (Colombia), Zuata luteofascia sp. nov. (Colombia). Ferorhinella brevis (Walker, 1851) comb. nov. In addition, descriptions are given for a new colour form of Mahanarva (M.) phantastica (Breddin, 1904) and a newly found variation in the male genitalia of Deoisella fasciata Costa \& Sakakibara, 2002.

Keywords. Cercopidae; Hemiptera; Neotropical; new taxa.

As plant feeders, the Cercopidae (spittle-bugs or froghoppers) sensu Metcalf (1961), are an important constituent of forest biodiversity and have become pests of sugar-cane and imported non-resistant pasture grasses in South America. Due to their relatively large size and often striking colour patterns many of the South and Central American species were described in the 'old' literature, with their types deposited in European museums. These poor early descriptions and the large number of inaccessible types may have contributed to the paucity of recent work on the group. In addition, due to the lack of adequate keys, it is difficult to identify species without access to a reference collection, although the colour patterns on these insects are useful to compare with original descriptions and colour plates. In the present work a new genus and nine new species are described together with the description of a new colour form of the high altitude Mahanarva phantastica (Breddin, 1904) and of a newly found variation in the male genitalia of Deoisella fasciata Costa \& Sakakibara, 2002. The status of the species as new, described herein, was made possible by a comparison of nearly all New World cercopid species, as part of a review in progress (CARVALHO \& WeBB, in prep.). The placement to genus has been made by comparison with similar described species in The Natural History Museum, London.

Abbreviations: BMNH, The Natural History Museum, London, UK; DZUP, Departamento de Zoologia, Universidade
Federal do Paraná, Curitiba, Brazil; MCTP, Museu de Ciências e Tecnologia, Pontifícia Universidade Católica do Rio Grande do Sul, Porto Alegre, Brazil.

\section{Ferorhinella gen. nov.}

Type species: Sphenorhina brevis Walker, 1851.

Moderately small species (7-8mm). Predominantly yellowish brown; fore wings (Fig. 1) reddish with dark brown markings. Head in dorsal aspect with width across eyes 1.2 times pronotal length; surface smooth, shining; pubescence fine, sparse, pale, sub-erect. Vertex and frontoclypeus with length 0.8 width between eyes, medial carina distinct on vertex only, interocular callosities shallow and ill-defined; ocelli very small, 1.5 times as far from base of head as from each other, separated by 3.0 times their own width. Postclypeus little inflated, obtusely rounded in profile, medial carina broad, lateral horizontal ridges weak; third antennal segment wider than long, rounded, single short arista subapical; rostrum extending to level of mid coxae. Disc of pronotum smooth, shining, finely and very shallowly punctate, pubescence as on head; width 1.7 times length, c.1.4 times width of head across eyes; frontolateral margins straight, median carina obsolete, anterior indentations very shallow and ill-defined. Scutellum with length c.1.2 times basal width, width c. 0.45 that of pronotum. Hind tibia with length slightly less 
than twice that of femur, sub-basal spine very small, distal spine large, with eleven apical spines; metatarsus with apical spines obscured by long setae. Fore wings sparsely and irregularly reticulate over apical 0.70 length; A1 distinct, A2 absent. Hind wings with $\mathrm{Cu} 1$ not abruptly thickened sub-basally, r-m situated at c. 0.65 length, $\mathrm{m}$-cu at 0.45 length, fused $\mathrm{Sc}$ and $\mathrm{R}$ separating at 0.45 length; proximal costal process at c. 0.25 length, with two spines, distal process at c. 0.60 length.

Male pygofer with a lateral process between anal tube and subgenital plate. Subgenital plate with apex acutely rounded; lateral lobes simple, length almost twice basal width; external margins sub-basally each with a cluster of very small tooth-like spines. Aedeagus slender, upright, weakly sinuate and distally curved ventrally in lateral aspect; apex produced into a slender, ventrally inclined, apically bifid process; gonopore small, apical. Parameres robust, horizontal, broadly rounded apically; a dorsal subapical process, hook-like, directed posteriorly and from its base a long, straight, spine-like process, directed ventrally.

Included species:

Ferorhinella brevis (Walker, 1851) comb. nov.

(Figs. 1, 34-37)

Sphenorhina brevis Walker, 1851: 692.

Tropidorhinella brevis; Fennah, 1968: 175.

Remarks. The single species from Brazil, is distinguished by its moderately small size and very distinctive male genitalia with the parameres broad apically with two subapical processes (Figs. 36-37) and the aedeagus with a single terminal, apically bifid, process (Figs. 34-35). The proportions of the head (Fig. 1) and the shape of the aedeagus and parameres are quite unlike those of other genera, including Tropidorhinella Schmidt, 1910 (Figs. 7 and 20), to which Sphenorhina brevis was consigned by Fennah (1968).

\section{Mahanarva (Ipiranga) bahiaensis sp. nov.}

(Figs. 2, 38, 39)

\section{Length: male (x1), $10.4 \mathrm{~mm}$}

Thorax dorsally and head blackish brown; thorax ventrally yellowish brown marked with dark brown. Fore wings (Fig. 2) dark brown, paler over radial area basally, with a transverse band at c.0.36 length and another at level of apex of clavus, whitish yellow. Male genitalia with subgenital plate elongate, lateral margins strongly incurved sub-basally with short stout spines. Parameres with subapical process broadly triangular, thereafter paramere apex abruptly tapered to acutely rounded apex. Aedeagus (Fig. 38) with lateral processes elongate, shaft in dorsoventral view (Fig. 39) relatively narrow throughout length with lateral margins slightly incurved sub-basally.

Holotype male. BRAZIL, Bahia: Camacã, 20.III.1980 (BMNH).

Remarks. This species can be distinguished by the two pale bands on the fore wings and the relatively narrow aedeagal shaft in dorsoventral view.

\section{Mahanarva (Mahanarva) phantastica (Breddin, 1904)}

(Figs. 3, 23)

Tomaspis phantastica Breddin, 1904: 58.

Mahanarva (Mahanarva) phantastica; Fennah, 1968: 186.

Material examined. COLOMBIA: 1 male, 1 female, Sta. Helena (Ant.), En Pasto Kikuyo, y Pasto Rye grass, viii. 1988; 2 males, 2 females, Zulaibar(?), V. Medellin; ECUADOR: 2 males, Banos, 6000' (BMNH).

Remarks. This high altitude species shows extreme color variation within the same population with red, yellow and black morphs present with variation in the degree of the black markings (pers. com. D. Peck). The specimen figured here and one other (Colombia, Sta. Helena) are mainly scarlet in colour (Fig. 3). This form has the aedeagus with longer processes and the shaft, distad of the processes, less elongate (Fig. 23). Like some other Mahanarva species, this species holds the fore legs away from the host plant when feeding (pers. com. D. Peck).

\section{Maxantonia bifurcata sp. nov.}

(Figs. 4, 24, 25)

Length: male(x1), $14.1 \mathrm{~mm}$.

Reddish brown, darker on dorsum. Fore wings (Fig. 4) with a very narrow yellow band across wing from apex of clavus, broadening at costal margin. Pygofer process robust strongly curved ventrally; subgenital plate tapered to apex with a subapical prominence from its outer margin; aedeagus, in lateral aspect (Fig. 25), sinuate with apex broad, a robust bifurcate process arising subapically from its dorsal surface; apex flange like laterally with flange extended dorsally into a short straight, laterally serrate, process and ventrally into a short hood like process.

Holotype male. ECUADOR: Mera, 26.I.1923, F. X. Williams $(\mathrm{BMNH})$

Remarks. Externally this species is most similar to M. catella (Jacobi, 1908) and M. cantator Schmidt, 1922 in having a very narrow yellow band on the fore wings. Its aedeagus however, is most similar to M. quadriguttata (Walker, 1851) from which it differs in having the arms of the subapical dorsal process more divergent and in having a ventral apical process.

\section{Neosphenorhina curvipenis sp. nov.}

(Figs. 5, 32, 33)

Length: male (x3), 10.0-10.9 mm; female (x1), $10.3 \mathrm{~mm}$

Head, thorax and abdomen pale yellowish brown, fore wings (Fig. 5) with a red apical spot margined with dark brown; basal antennal segments, antennal ledge (male), rostrum, apex of femur, tarsi and base and apex of tibia, dark brown. Aedeagus (Figs. 32, 33) with shaft strongly curved dorsally, a very small 

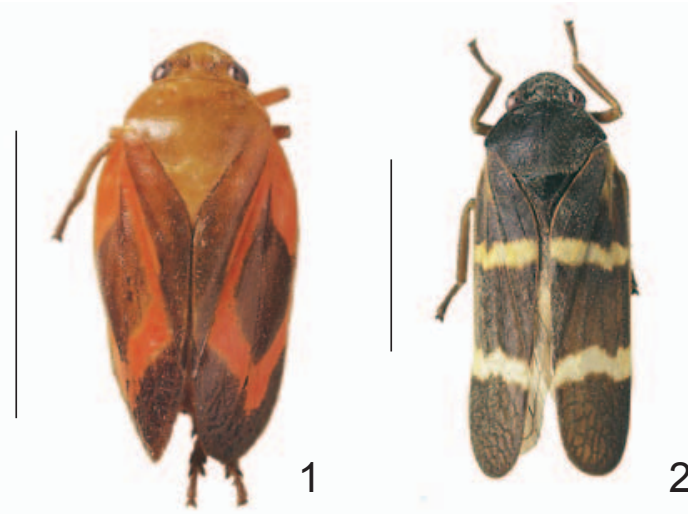

2

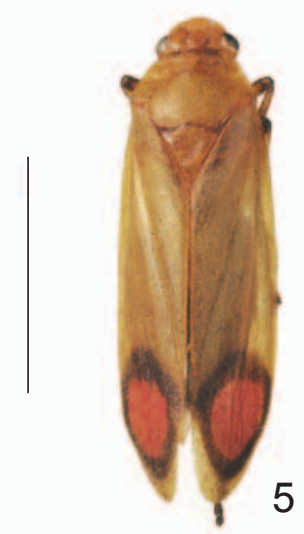

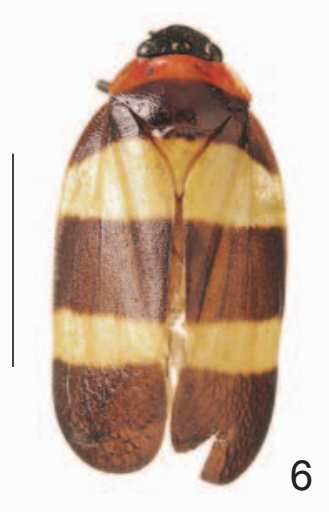
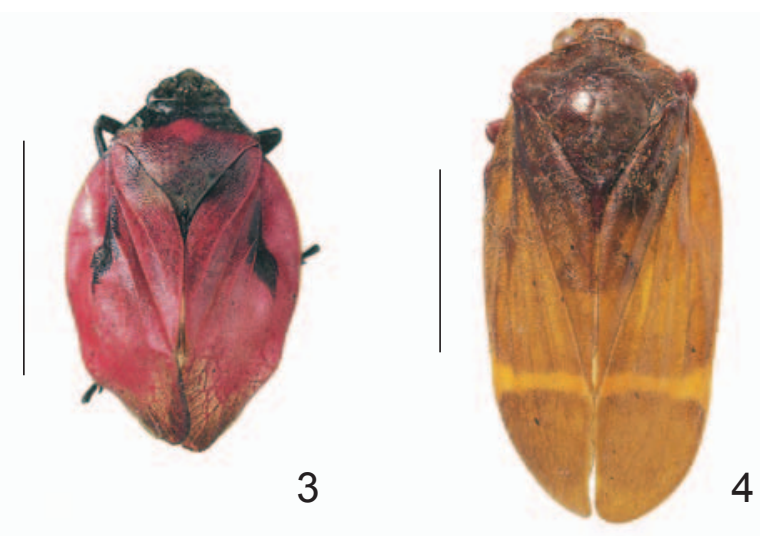

4

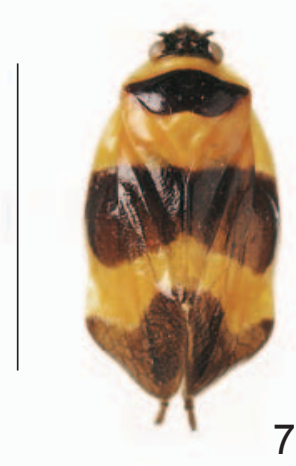

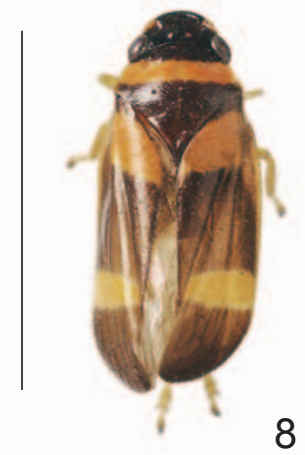

Figs. 1-8. Dorsal habitus (holotypes except where indicated, pins digitally removed, scale line $=5 \mathrm{~mm}$ ). 1, Ferorhinella brevis (Brazil, Blumenau, BMNH); 2, Mahanarva (Ipiranga) bahiaensis; 3, Mahanarva (M.) phantastica (Colombia, male, BMNH); 4, Maxantonia bifurcata; 5, Neosphenorhina curvipenis (paratype male); 6, Sphenorhina nigricephala; 7, Tropidorhinella onorei; 8, Zuata luteofascia.

acute spine dorsally on each side at c. 0.7 length.

Holotype male. BRAZIL: Santa Catarina, Corupá, XI.1953, A. Maller (BMNH). Paratypes: BRAZIL: 1 male, Corupá ("Hansa Humboldt"), 23.X.1928, A. Maller (BMNH); 1 female, Est. São Paulo, 16.XII.1928 (BMNH); 1 male, Joinville, SC, 23.I.1972 (DZUP).

Remarks. This species has identical markings to $N$. ocellata (Walker, 1851) but differs externally in its smaller size and overall yellowish brown colour rather than reddish brown. In the male genitalia it differs by its more robust aedeagus with the shaft more strongly and evenly curved from base to apex with processes slightly more basad. The paratype from Corupá has the same data label as a specimen of $N$. ocellata $(\mathrm{BMNH})$.

\section{Sphenorhina nigricephala sp. nov.}

(Figs. 6, 28, 29)

Length: male (x2), $11.1 \mathrm{~mm}$

Head dark brown. Pronotum yellow tinged with red anteriorly, dark brown posteriorly. Fore wings (Fig. 6) dark brown with a broad band sub-basally, narrowing towards costal margin and a narrower band subapically, yellow. Venter yellow, variably tinged with red; legs (except hind femur) and patch on mesosternum brown. Parameres with subapical process narrow and bearing a truncate dorsal tooth. Aedeagus, in lateral aspect (Fig. 28), elongate, narrow over distal half, slightly expanded over basal half; gradually expanded from base to apex in dorsoventral view (Fig. 29); ventral process arising sub-basally and extended to point c. 0.75 length, from base to apex, of shaft.

Holotype male. ECUADOR: Tena, IV.1923, F.X.Williams (BMNH). Paratype male, same data as holotype, 20.IV.1923.

Remarks. This species is similar to S. johannae (Distant, 1908) and S. latifascia Walker, 1851 in colour pattern. From the former it differs in having the aedeagus broad rather than narrow apically, in dorsoventral view, and from the latter (females only) it is smaller with the subapical yellow band of the fore wings of similar width throughout length or slightly narrowing towards clavus (holotype) rather than more distinctly narrowing in $S$. latifascia. A series of specimens from Ecuador, Camelos, 1500', I.1918, J.B. Rorer (1 male, 2 females, 1 ?, BMNH) may be this species but the aedeagus of the single male is noticeably more expanded apically in dorsoventral view. 


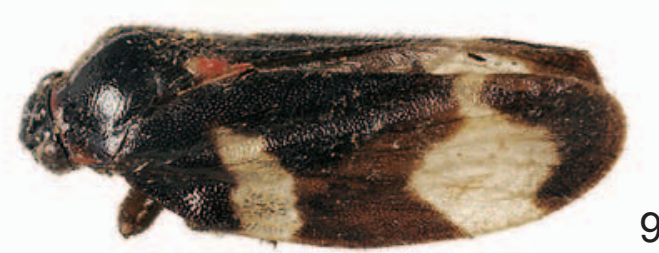

9

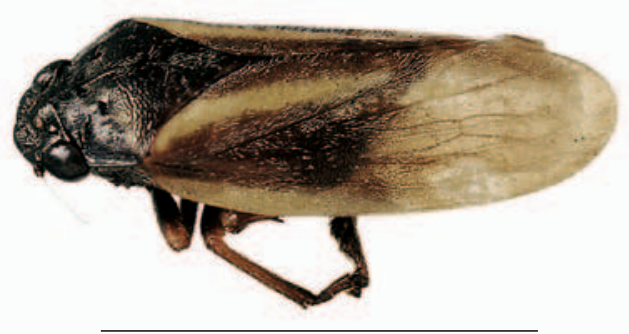

11

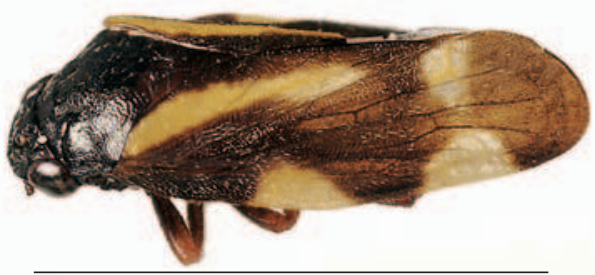

13

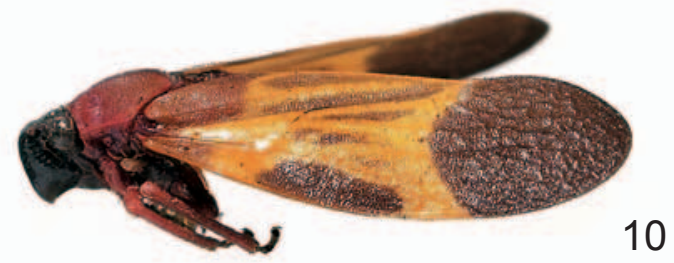

10

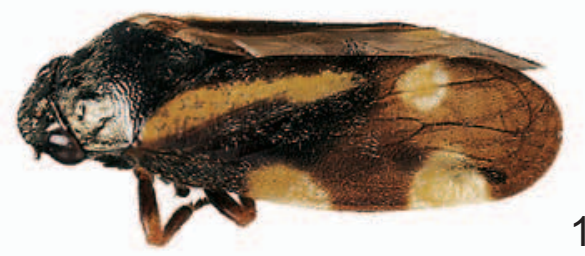

12

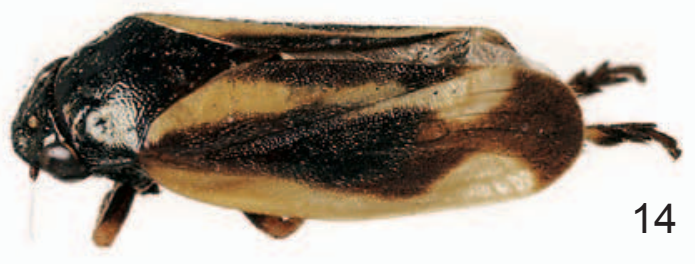

Figs. 9-14. Left lateral habitus (paratypes, pins digitally removed, scale line $=5 \mathrm{~mm}) . \mathbf{9}$, Sphenorhina minuta; 10, S. brevispina; 11, Deois (Deois) knighti; 12-13, Deois (Deois) sexpunctata (13, damaged pronotum digitally corrected); 14, Deois (Pandysia) constricta.

\section{Sphenorhina minuta sp. nov.}

(Figs. 9, 30, 31)

Length: male (x2), 6.2-7.5 mm

Dorsum dark brown; anterior area of pronotum and apex of scutellum, yellow variably tinged with red; fore wings (Fig. 9) with an irregular, broad, yellowish, transverse band sub-basally, extending from costal margin onto clavus but not reaching claval margin; another band extending from costal margin to apex of clavus subapically, greatly broadened medially over radial, medial, and cubital areas. Venter brown variably tinged with red. Paramere with subapical process with a pair of short apical teeth. Aedeagus, in lateral view (Fig. 30), very narrow, broad throughout length in dorsoventral view (Fig. 31); ventral process absent.

Holotype male. BOLIVIA: Yungas del Palmer, 2000m, IV.1948, Schoenfelder (BMNH). Paratype male, same data as holotype (BMNH).

Remarks. This species is similar to S. fissurata Lallemand, 1938 in its small size and fore wing markings but differs in its broader medial area of the yellowish posterior band of the fore wing. In the male genitalia the aedeagus is similar to $S$. fissurata and $S$. veteranus Jacobi, 1908 but the parameres have a single subapical process with a pair of short apical teeth.

\section{Sphenorhina brevispina sp. nov.}

(Figs. 10, 26, 27)

Length: male (x1), $12.2 \mathrm{~mm}$.

Head blackish brown, antennal ledges paler brown. Thorax reddish brown, mesosternum brown. Fore wings (Fig. 10) dark brown with veins over basal two thirds heavily marked with yellow the latter forming a concave band across wing from scutellum. Parameres with a single subapical process, tapered to apex. Aedeagus slightly increasing in width from base to mid-length in lateral view (Fig. 26), with a very short medial process, arising slightly distad from mid-length on ventral surface.

$$
\text { Holotype male. ECUADOR(?): 'Sebouday'(?), (BMNH). }
$$

Remarks. The country of origin of the holotype is uncertain. It bears a single hand-written data label probably reading 'Sebouday', with the fourth letter partially obscured by a pinhole. It also bears a printed number '2609' and a det. label, in 

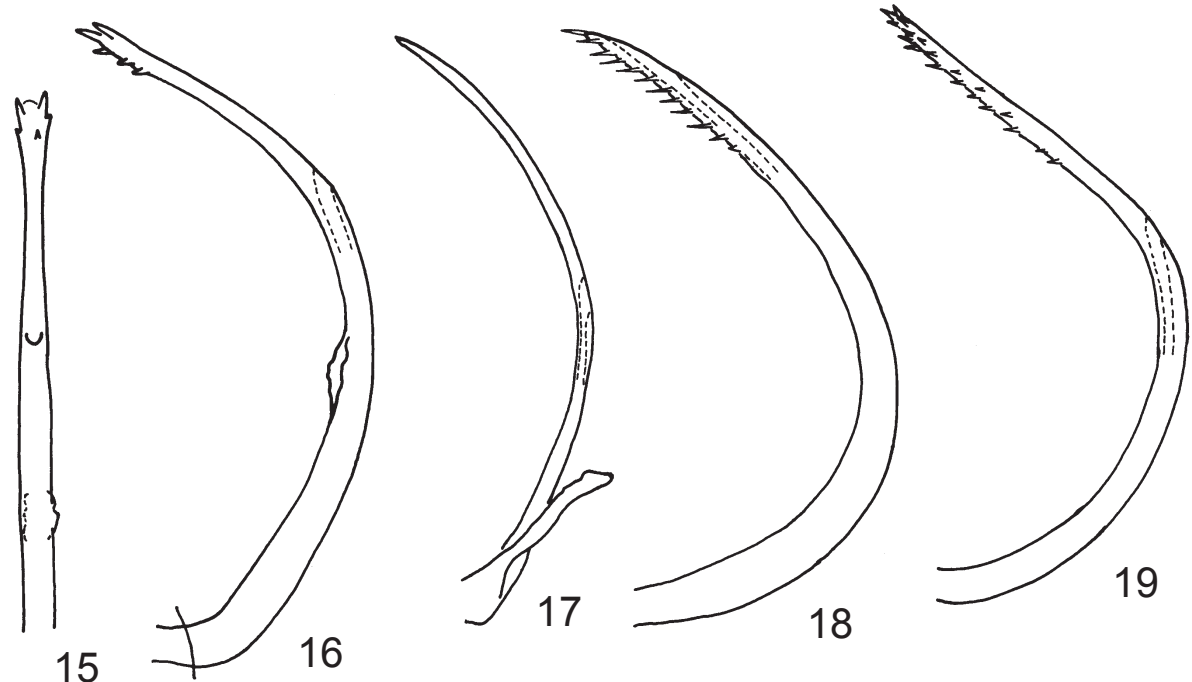

15

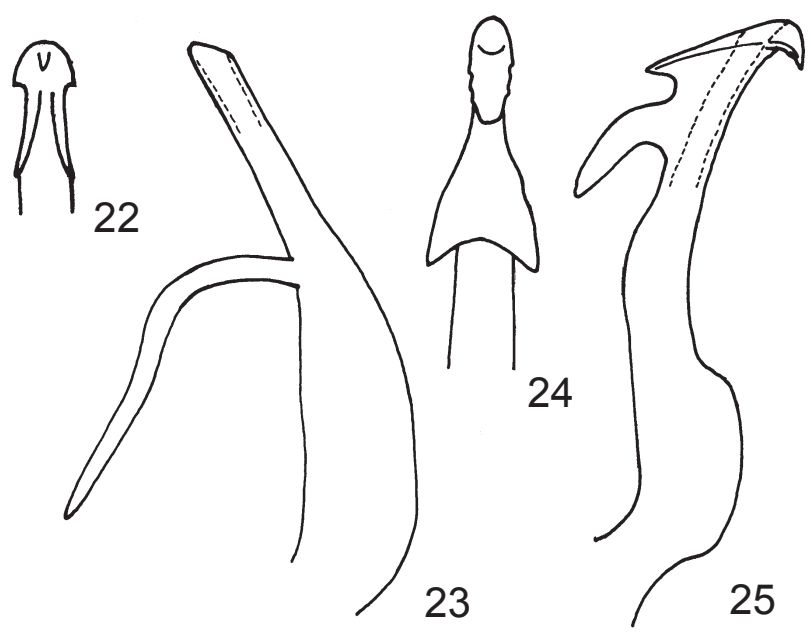

Figs. 15-25. Male genitalia (lateral view of holotype aedeagus, except where indicated). 15,16, Deois (Pandysia) constricta (15, apex of aedeagus ventral view); 17, Deois (Deois) sexpunctata; 18, Deois (Deois) knighti; 19, Deoisella fasciata (from specimen from Mato Grosso, BMNH); 20, Tropidorhinella onorei (from Paratype from Tena); 21, 22, Zuata luteofascia (21, paratype, 22, apex of aedeagus, ventral view, holotype); 23, Mahanarva (M.) phantastica (from specimen from Colombia, BMNH); 24, 25, Maxantonia bifurcata (24, aedeagus, dorsal view).

Distant's hand, reading 'clarivenosa Jacobi', the species under which the specimen was placed (in Sphenorhina) in the BMNH collection. A specimen of S. clarivenosa Jacobi, 1908 (BMNH), also from Distant's collection, bears the number 2683 in the same style, unfortunately this specimen lacks all data. A computer gazetteer search, using first the whole name and then various parts of the name, found only one possibility for the name on the type specimen, Sebundoy in Ecuador. As Ecuador is one of the countries from where S. clarivenosa occurs, this may be the possible locality for the holotype. Although similar to $S$. clarivenosa, the new species has the yellow marking on the fore wing veins much more pronounced and the process of the aedeagus short rather than long.

\section{Tropidorhinella onorei sp. nov.}

(Figs. 7, 20)

Length: male (x1), 6.5 mm; female (x3), 6.0-6.6 mm
Yellow; head dorsally, posterior 0.6 of pronotum, base of clavus, a broad band across fore wings touching apex of scutellum and apices of fore wings, rostrum, fore and mid femora, mid and hind tibiae, fore tibiae, tarsi and a patch on mesosternum, dark brown. Parameres with subapical lobe bifurcate; aedeagus (Fig. 20) relatively robust, with an elongate dorsal process and short ventral process, apically.

Holotype male. COLOMBIA: Caqueta, Florencia, 480m., 31.X.5.XI.1971, M. Cooper. Paratypes: ECUADOR: 1 male (figured), 1 female, Tena, 4.IV.1923, F.X. Williams; 1 female, Napo, Tena, 9-14.XII.1971, M. Cooper (BMNH); 1 female, Coca, 250m, V-VI.1982, G. Onore.

Remarks. This species can be distinguished from T. inflata (Jacobi, 1908) and T. montana Schmidt, 1918 by its yellow rather than red markings and in the male genitalia by the characters noted in the above description.

The species is named for Giovanni Onore a notable collector of insects in Ecuador, including one of the paratypes. 


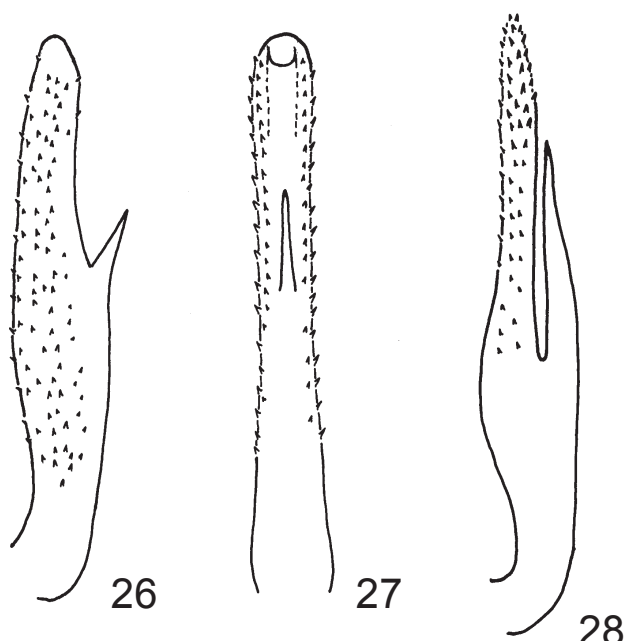

28

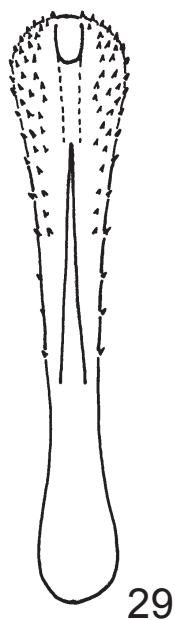

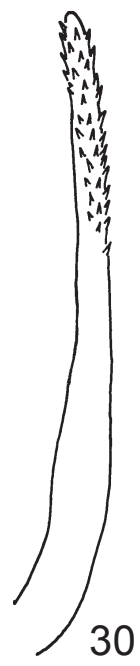
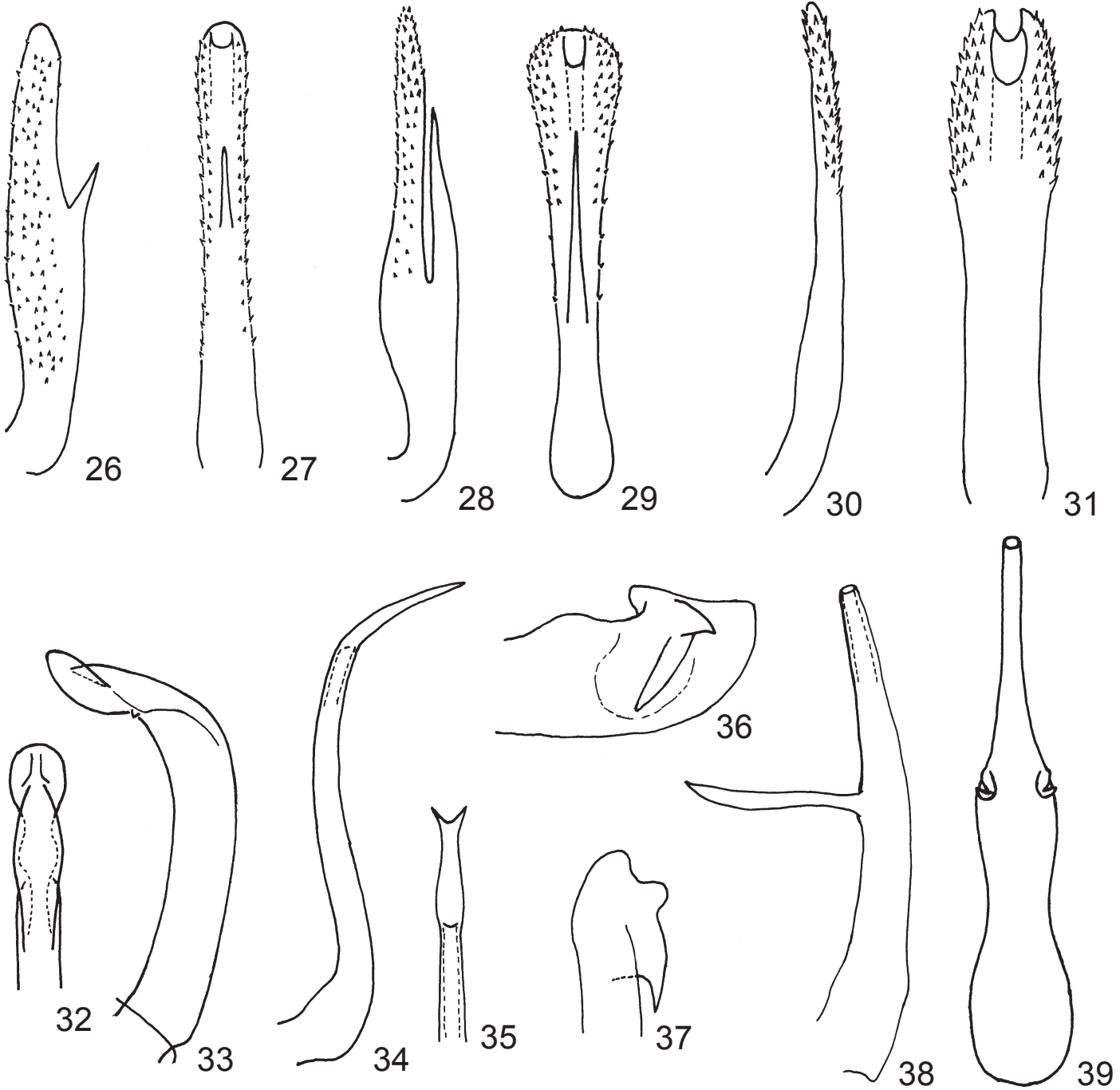

Figs. 26-39. Male genitalia (holotype aedeagus, in left lateral and ventral view respectively, except where indicated). 26, 27, Sphenorhina brevispina; 28, 29, Sphenorhina nigricephala; 30, 31, S. minuta; 32, 33, Neosphenorhina curvipenis; 34-37, Ferorhinella brevis (Brazil, Constancia (BMNH), 36-37, apex of right paramere, left lateral and dorsal view respectively); 38-39, Mahanarva (Ipiranga) bahiaensis (39, aedeagus, dorsal view).

\section{Zuata luteofascia sp. nov.}

(Figs. 8, 21, 22)

Length: male (x2), 5.8-6.3 mm; female (x2), $6.8 \mathrm{~mm}$

Blackish brown, basal antennal segments and edge of antennal ledge, pale brown; thorax including legs predominantly yellowish brown with a yellowish-orange band across middle of pronotum; fore wings (Fig. 8) with a patch on base of clavus and adjacent area of Cubitus and a band across adjacent apex of clavus, yellowish-orange. Subgenital plate elongate, acute apically. Aedeagus (Figs 21,22) with a short and moderately long pair of subapical processes on each side and a short medial apical process from the ventral surface; gonopore apical, indistinct.

Holotype male. COLOMBIA: Rio Claro, Pto. Trunfo (Ant.), VI.1985, R. Vélez (BMNH). Paratypes: 1 male, 3 females, same data as holotype (BMNH, 1 female MCTP).
Remarks. This species is similar to Z. bimaculata (Lallemand, 1938) in size and coloration but has two rather than three pairs of aedeagal processes.

\section{Deois (Deois) knighti sp. nov.}

(Figs. 11, 18)

Length: male (x 2), $7.2 \mathrm{~mm}$; female (x 9), 7.5-8.3 mm.

Blackish brown; pronotum posteriorly, scutellum, fore wings and variably on thorax ventrally, paler brown. Costal margin of fore wings (Fig. 11) with pale yellow band, distally slightly expanded, the latter sometimes forming a small spot; clavus with a pale yellow band medially, extending apically onto adjacent area of Cubitus. Subgenital plate with apex shallowly concave with ventral lobe slightly more elongate than dorsal lobe. Aedeagus (Fig. 18) with a row of spines on each dorsolateral surface, extending over apical 0.25 length; gonopore 
elongate, situated apically on ventral surface.

Holotype male. BRAZIL: Mato Grosso, $12^{\circ} 49^{\prime} \mathrm{S} 51^{\circ} 45^{\prime} \mathrm{W}$, Cerrado, 12.XII.1968, W.J. Knight (DZUP). Paratypes: BRAZIL, Mato Grosso, 1 male, 5 females, same data as holotype except various dates between 13.XI.1968.-14.I.1969; 1 female, Corrego do Gato, 20.XII.1968, all W.J. Knight; 1 female, $12^{\circ} 50^{\prime} \mathrm{S} 51^{\circ} 45^{\prime} \mathrm{W}, 15 . \mathrm{II} .-8 . \mathrm{III} .1968$, B.E. Freeman; 5 females, $12^{\circ} 50^{\prime} \mathrm{S} 51^{\circ} 47^{\prime} \mathrm{W}$, various dates between 9.II.11.III.1968, O.W. Richards (BMNH, MCTP and DZUP).

Remarks. This species is very similar to D. correntina (Berg, 1879), but the latter is slightly larger ( $9.6 \mathrm{~mm}$ - male type) and the pale costal band of the forewings is continuous. In the male genitalia the subgenital plate is more shallowly concave apically in the new species and the aedeagus is slightly narrower, in lateral and ventral view.

\section{Deois (Deois) sexpunctata sp. nov.} (Figs. 12, 13, 17)

Length: male (x10), 6.0-6.6 mm; female (x10), 6.1-6.6 mm.

Blackish brown. Thorax marked with paler brown ventrally. Fore wings blackish to dark brown; costal margin with a pale yellow spot sub-basally and sub-apically; a golden or pale yellow medial band extending from base to near apex of clavus and a disassociated pale yellow spot at apex of clavus (Fig. 12), the latter sometimes nearly touching distal costal spot (Fig. 13). Aedeagus (Fig. 17) very narrow, with a pair of basal processes; gonopore short, situated at mid-length of ventral surface.

Holotype male. BRAZIL: Mato Grosso, $12^{\circ} 49^{\prime} \mathrm{S} 51^{\circ} 45^{\prime} \mathrm{W}$, 15.XI.1968, W.J. Knight (DZUP). Paratypes: BRAZIL, Mato Grosso, 8 males, 12 females, same data as holotype except various dates between

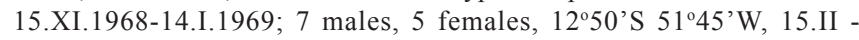
8.III., III.1968, B.E. Freeman (BMNH, MCTP and DZUP).

Remarks. This species can be distinguished by its fore wing markings and very narrow aedeagus with a pair of basal processes. Only part of the type series is sufficiently well preserved for measurement purposes.

\section{Deois (Pandysia) constricta sp. nov.}

(Figs. 14-16)

Length: male (x1), 6.2 mm; female (x3), 6.0-7.3 mm.

Blackish brown. Thorax marked with paler brown ventrally. Fore wings (Fig. 14) dark brown with a pale yellow band along costal margin and middle of clavus, with distal areas of both bands expanded and terminating sub-apically. Aedeagus (Figs. 15-16) with a group of scattered spines at apex, gonopore short, situated at two-thirds distance from base to apex on ventral surface; a flange-like expansion on each side of dorsal surface slightly basad of mid-length.

Holotype male. BRAZIL: Mato Grosso, $12^{\circ} 49^{\prime} \mathrm{S} 51^{\circ} 45^{\prime} \mathrm{W}$, 19.XI.1968, W.J. Knight (DZUP). Paratypes. 1 male, same data as holotype; 2 females, same data as holotype except, 1 female, 13.XI., 1 female, $12^{\circ} 50^{\prime} \mathrm{S} 51^{\circ} 47^{\prime} \mathrm{W}$, II.-III.1968, O.W. Richards (BMNH and DZUP).

Remarks. This species is similar to D. schach (Fabricius, 1787) in the shape of the aedeagus but can be distinguished by the subapical constricted brown medial area of the forewing and in the aedeagus by the more basal flanges.

\section{Deoisella fasciata Costa \& Sakakibara}

(Fig. 19)

Deoisella fasciata Costa \& Sakakibara, 2002: 206, figs. 10-12, 16.

Material examined. BRAZIL: 4 males, 8 females, Mato Grosso, $12^{\circ}$ 49'S 51 $45^{\prime}$ 'W, various dates, W.J. Knight (BMNH); 1 male and 1 female (paratypes), Campo Grande, Mato Grosso do Sul, VIII. 1983 (BMNH).

Remarks. The non-type males examined differ from the types in having the aedeagal shaft significantly longer distad of the gonopore (compare Fig. 11 of COSTA \& SAKAKIBARA 2002 with Fig. 19).

Acknowledgements. The authors wish to thank Dr. Albino M. Sakakibara, Dr. D. Peck and Dr. K. G. A. Hamilton for their help during the course of the work

\section{REFERENCES}

Costa, A. C. F. da \& A. M. Sakakibara. 2002. Reestruturação do gênero Deois Fennah; descrição de um novo gênero e de novas espécies (Homoptera, Cercopidae, Tomaspidinae). Revista Brasileira de Entomologia 46: 195-207.

FENNAH, R. G. 1968. Revisionary notes on the new world genera of Cercopid froghoppers (Homoptera: Cercopoidea). Bulletin of Entomological Research 58: 165-190.

Metcalf, Z. P. 1961. General Catalogue of the Homoptera, Fascicle VII, Part 2 Cercopidae. U. S. Department of Agriculture, Agricultural Research Service, 607 pp.

WALKER, F. 1851. List of the specimens of Homopterous insects in the collection of the British Museum 3: 637-907. 